\title{
MODELING OF SMOKE CONTROL IN UNDERGROUND PARKING-GARAGE FIRES
}

\author{
Beline Alianto ${ }^{1}$, Nabilla Astari ${ }^{1}$, Darendra Nareshwara ${ }^{1}$, Yulianto Sulistyo Nugroho ${ }^{1 *}$ \\ ${ }^{1}$ Department of Mechanical Engineering, Faculty of Engineering, Universitas Indonesia, Kampus UI \\ Depok, Depok 16424, Indonesia
}

(Received: February 2017 / Revised: July 2017 / Accepted: December 2017)

\begin{abstract}
Smoke is the real threat in a fire in an enclosed, underground parking garage, and is a significant issue and very critical for firefighters dealing with fire. Special attention should be paid to fire safety, especially for those with multiple floors underground. A model of the smoke movement in a basement was established using Fire Dynamics Simulator (FDS) 6.0 software. In this paper, the study undertaken used a basement model of $60 \mathrm{~m}$ (length) $\times 30 \mathrm{~m}$ (width) $\times 3 \mathrm{~m}$ (height) and has three typical floors. Smoke ventilation shafts were provided for the basement. A well-controlled liquid pool fire with a heat release rate (HRR) of $2 \mathrm{MW}$ was used as an input parameter. The ventilation strategy was achieved through a mechanical exhaust fans and makeup air fans. The required ventilation was based on the air changing ten times per hour. The following parameters were varied: the location of the fire, the presence or absence of sprinklers, the presence or absence of a smoke-extraction system, the presence or absence of openings for incoming air, and the presence or absence of a jet fan and ducting. The impact of jet fans (induction type) was also addressed in several simulations. Smoke modeling was investigated under different fire scenarios. Simulations were conducted for smoke and heat control using forced, mechanical, horizontal ventilation. When the combination of a jet fan and ducting was applied, the fastest time for smoke removal was achieved compared to the other scenarios.
\end{abstract}

Keywords: Basement ventilation; Fire; Jet fan; Mechanical fan; Smoke exhaust

\section{INTRODUCTION}

Underground parking garages generally provide enclosed conditions. While the effectiveness of fire protection systems is commonly associated with active water-based sprinkler and hydrant protection systems, smoke movement is critical and is subject to failure because most design engineers do not have a proper understanding of what happens when a fire breaks out. As smoke flows through the building, it is restricted by the frictional forces that inevitably exist due to the construction of the building. A large amount of smoke is generated, which leads to unpredictable smoke movement and poor conditions for evacuation. Chow (1998) divides underground fire protection systems into mechanical ventilation systems and fire protection systems.

Various past experimental studies of single vehicle fires was done by Mangs and KeskiRahkonen (1994), Shipp and Spearpoint (1995), and Cheng and John (2002), for which the main objective was to determine heat release rate (HRR) of vehicle fires. Further investigations have been carried out in enclosed-basement fires, which focus on smoke movement (Hwang \&

\footnotetext{
*Corresponding author's email: yulianto@eng.ui.ac.id, Tel. +62-21-7270032, Fax. +62-21-7270033

Permalink/DOI: https://doi.org/10.14716/ijtech.v8i7.779
} 
Edwards, 2005; Vauquelin \& Telle, 2005) and fire development (Ingason \& Lonnermark, 2005). Moreover, the full-scale experiments on modern cars reveal high HRR values for fires, which exceed $16 \mathrm{MW}$ when three cars are on fire (Horvath et al., 2013). Most of the building's utilities are located in the basement. Electrical cables are also categorized as a fire hazard. Pangaribuan et al. (2016) concludes that the spread of fire in polyvinyl chloride (PVC) insulated cables can be eliminated by reducing the oxygen concentration.

Engineering standards, regulations, and codes are always used; they are briefly explained in the framework of prescriptive codes. However, different practices are carried out. Performancebased fire safety will be applied in the near future; for example, a study on performance-based fire safety was conducted by Sujatmiko et al. (2014).

Common practice concerns the use of mechanical, horizontal ventilation, which extracts hot smoke from certain points in the parking garage and keeps it clear from smoke. This is similar to longitudinal ventilation in tunnels (Gao et al., 2012). Parking garages, however, have a substantially different height-to-width aspect ratio compared to tunnels. Consequently, the principles longitudinal ventilation, which have been developed and predicted for tunnels, becomes questionable for parking garages because of the complex flow patterns that might occur.

Full-scale experiments are the best way to obtain valuable information. For instance, Horvarth et al. (2013) performed a full-scale test and a reduced-scale test of parking garages on fire using different heat release values $(500-4,000 \mathrm{~kW})$ with different inlet air velocities $(0.3-2 \mathrm{~m} / \mathrm{s})$, and derived the empirical critical velocity based on the heat rate. However, the huge costs and the limited number of tests mean the study of this topic is challenging.

While most of the aforementioned investigations were done experimentally, Tilley et al. (2012) conducted a large set (more than 350) of computational fluid dynamics (CFD) simulations have been used as "numerical experiments." In addition, Deckers et al. (2013a) also presents CFD simulations for large parking garages and full-scale experiments for car-park fires. Wu et al. (2017) applies natural underground ventilation in a study, and concludes that the total ventilation area and the height of the shafts are the key factors influencing smoke control, and that multistage shafts can be used for smoke control in the platform layer due to the formation of the stack effect.

Common practice for ventilation is having a mechanical exhaust at each level with make-up air provided by a fan and transported via the impulse ventilation from jet fans. An advantage of jet fans is that they eliminate air-distribution ductwork within the parking garages, and thus reduce supply and exhaust air-flow resistance. Various studies have been done on jet fans; for example, Viegas (2010) ran a numerical CFD simulation involving the ventilation for covered parking garages to investigate the control the smoke in the event of a fire, and to determine the interaction between the fire ceiling jet and the flow driven by the jet fans.

A full-scale experiment on car-park fires with jet-fan ventilation was done by Deckers et al. (2013b) reveals that the impact of the exact position of the extraction fans on the smoke pattern is small when the extraction fans are not close to the fire source. This study also suggests that the primary effect of jet fans (induction type, $50 \mathrm{~N}$ ) does not have a significant impact on the global flow pattern, and, for the cooling effect to be observed, the jet fans must not be in a smoke-filled region. Other numerical simulations include the research conducted by Lu et al. (2011) on impulse ventilation systems, the study on the impact of jet fans during the activation of sprinklers in basement fires performed by Enright (2014), and an investigation of smoke movement in basement structures by Arini (2017), which uses a reduced-scale model and FDS simulation. 
Most of the studies discussed previously include a model for a single-story underground parking garage. It is also important to consider multi-story basements. Furthermore, only limited fire scenarios were investigated. This paper discusses a case study undertaken on a three-story underground parking-garage building of approximately $1800 \mathrm{~m}^{2}$, with each floor of the underground car-park building being approximately $60 \mathrm{~m}$ (length) $\times 30 \mathrm{~m}$ (width) $\times 3 \mathrm{~m}$ (height). Different locations of fires breaking out are studied. This paper focuses on smoke modeling and the prediction of smoke movement in several fire scenarios. The time required to clear the smoke from the basement is also discussed. The characteristics and prediction of smoke movement when fires break out on different floors are elaborated.

\section{SMOKE VENTILATION}

Automobile parking garages can be either enclosed or partially opened. Partially open parking garages are generally above ground with open sides. A combination of natural and forced ventilation can be used for partially open parking garages. Ventilation in enclosed underground spaces presents many concerns. American National Standards Institute (ANSI) / American Society of Heating, Refrigerating and Air-Conditioning Engineers (AHSRAE) 62.1 recommends that a flat ventilation rate of $0.0075 \mathrm{~m}^{3} /\left(\mathrm{s} . \mathrm{m}^{2}\right)$ equal to $6 \mathrm{ACH}$ is used for enclosed parking garages (ASHRAE Handbook, 2015).

The use of mechanical intake fans can cause problems with mechanical extraction. This is because the exhaust air that is extracted has a greater volume than the inlet air. As the fire grows and declines, there is mismatch in volume between the inlet air and the extracted, warmed air. A moving airstream that has a lower pressure than the still air will attract the stationary air toward itself. The force of attraction increases as the velocity of the airstream increases. The system should be designed to run in two parts; commonly, each part is arranged so that $50 \%$ of the outlets are at high levels and $50 \%$ are at low levels, according to many smoke ventilation codes (Chartered Institution of Building Services Engineers Guide B [CIBSE], 2005) and BS 7346-7:2006 (British Standards Institute, 2006). Ramps can also serve as natural ventilation openings.

\section{SETUP OF THE SIMULATION}

In the simulations, a basic configuration was chosen for the parking garage. In this configuration, as shown in Figure 1, the underground parking garage has three floors below ground containing the fire source and an array of sprinklers. The model's size is $64 \mathrm{~m}$ (length) $\times$ $30 \mathrm{~m}$ (width) $\times 13 \mathrm{~m}$ (height). Intake and exhaust ventilation shafts that are $2 \mathrm{~m}$ wide are provided at the left and right sides of the basement. For expedience of calculation, the model's domain is deliberately set to discrete cells of size $50 \mathrm{~cm} \times 50 \mathrm{~cm} \times 25 \mathrm{~cm}$ in all simulations, which results in 199,680 cells in this case. The simulation is performed using Fire Dynamics Simulator (FDS) V.6.

The major assumption that was applied in this case is that the flow of smoke throughout the building occurs steadily. It was also assumed that there was also negligible migration of smoke between floors through the floor slabs compared to the amount of smoke that travels vertically. The entire front and back wall were considered to be adiabatic, meaning there would be no additional heat loss from the structure, while the two walls were modeled to have smoke extraction on one side and air entering on the opposite side. The ventilation air-flow pattern was essentially unidirectional.

The dimensions of the pool fire were $1 \mathrm{~m} \times 1 \mathrm{~m}$. The Heat Release Rate (HRR) of the fire is $\mathrm{q}=$ $2.000 \mathrm{~kW} / \mathrm{m}^{2}$. In this case, a fast $\mathrm{t}^{2}$ growth rate was assumed. The $\mathrm{CO}$ yield $\left(\mathrm{Y}_{\mathrm{CO}}\right)$ was taken to be 0.006 and the soot yield $\left(Y_{s}\right)$ was 0.015 . The fuel chosen was heptane is selected as a fuel. 
Three locations of fire sources were simulated among those fire scenarios. A few sprinklers were added above the fire source and separated to such a distance that each sprinkler covered a protection area of $12 \mathrm{~m}^{2}$. Each sprinkler also operated at 0.5 bar pressure and had a $\mathrm{K}$-value of 80, which met the conditions for the category of ordinary hazard (National Fire Protection Agency [NFPA], 2013). Three sprinklers are then separated from each other by $4 \mathrm{~m}$ in groups as indicated by the blue color dots in Figure 1. Table 1 shows the configuration of the mechanical fans designed for use in the basement.


Figure 1 Building model and position of mechanical fans

The sizing of every fan is based on the air changing ten times per hour for the basement during the fire, resulting in an air-flow quantity of $7.5 \mathrm{~m}^{3} / \mathrm{s}$ per unit for the exhaust and intake fans. Moreover, the jet fans are necessary because of the advantages they provide through eliminating the air-distribution ductwork within the parking garages. Therefore, in order to push air from air the intake side to the negative-pressure smoke-extract side, the parking-garage models contain three rows of jet fans. Each row consists of five jet-fan units, each with a capacity of $2.0 \mathrm{~m}^{3} / \mathrm{s}$.

The simulation was run for ten fire scenarios (FS). There were neither sprinklers nor mechanical exhaust fans for FS1 and FS2, but both existed in FS3. Mechanical fans were provided in FS4. Two units of make-up air fans were installed to deliver make-up air from the atmosphere to the parking garages. 
Table 1 Mechanical fans specification

\begin{tabular}{lc}
\hline \multicolumn{2}{c}{ Without ductwork (Fire Scenarios 4-9) } \\
\hline Basement 3: SMF-B3/1,2; SMF-B2/1,2; SMF-B1/1,2 & Capacity of each fan \\
Basement 2: MAF-B3/1,2; MAF-B2/1,2; MAF-B1/1,2 & $@ 7.5 \mathrm{~m}^{3} / \mathrm{s}$ \\
Basement 1: Jet fans, 15 units, three rows with five fans/row & $@ 7.5 \mathrm{~m}^{3} / \mathrm{s}$ \\
\hline \multicolumn{2}{c}{ With ductwork (Fire Scenario 10) } \\
Basement 3 & Capacity of each fan \\
\hline MAF-B3/1,2; MAF-B2/1,2 & $@ 7.5 \mathrm{~m}^{3} / \mathrm{s}$ \\
EF-B3/H-1; EF-B3/H-2 & $@ 3.75 \mathrm{~m}^{3} / \mathrm{s}$ \\
EF-B3/L-1; EF-B3/L2 & $@ 2.5 \mathrm{~m}^{3} / \mathrm{s}$ \\
Jet fans, five units/row, three rows & $@ 2 \mathrm{~m}^{3} / \mathrm{s}$ \\
\hline
\end{tabular}

Half of the basement was treated as an extraction zone and the other was the make-up air zone. The position of the mechanical fans can be seen in Figure 2.

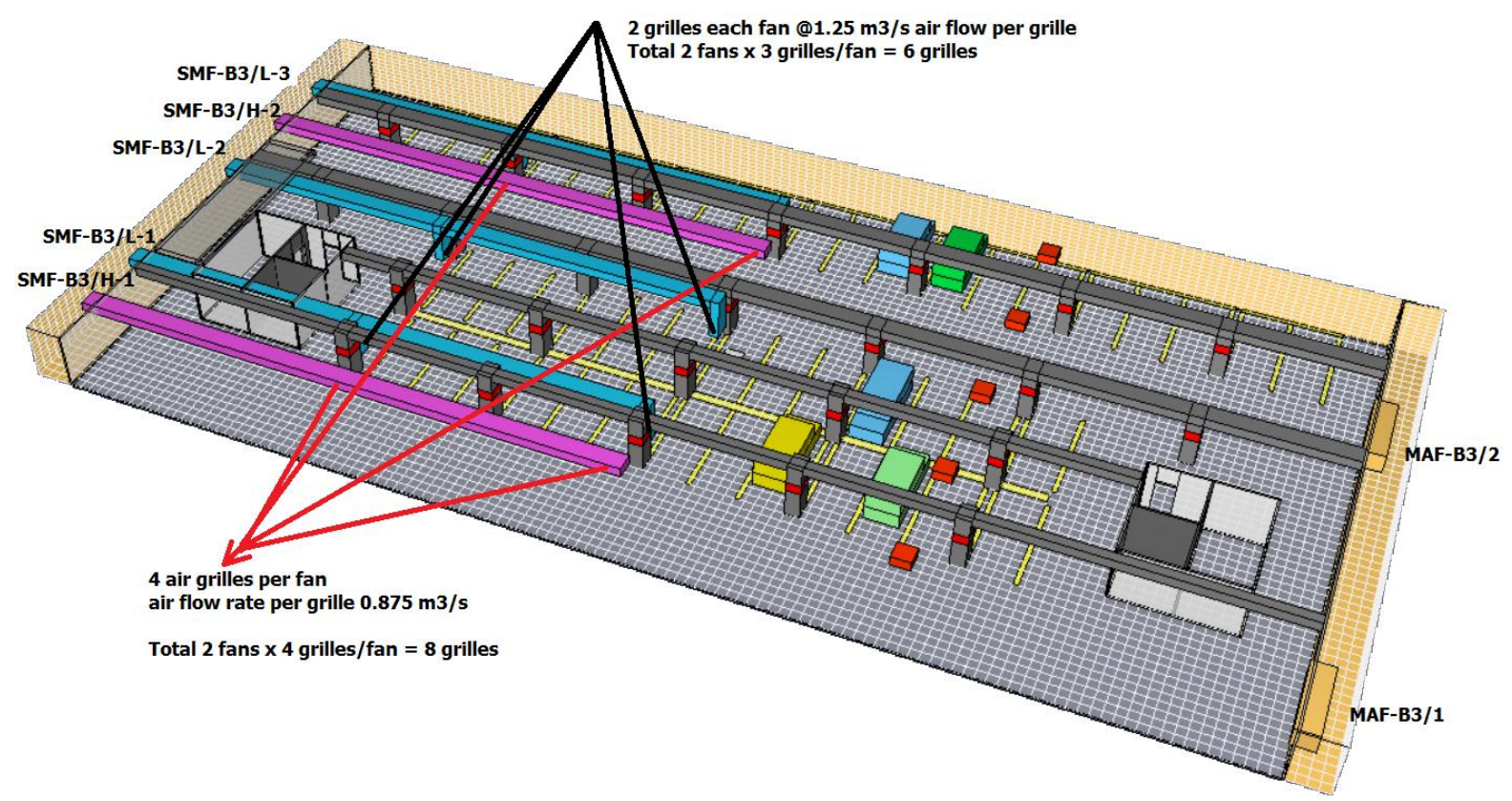

Figure 2 Setup simulation for FS10

Table 2 Availability of the fire protection devices

\begin{tabular}{|l|l|l|l|l|l|l|}
\hline & Sprinkler & $\begin{array}{l}\text { Smoke } \\
\text { Extract } \\
\text { Fan }\end{array}$ & $\begin{array}{l}\text { Make-up } \\
\text { Air Fan }\end{array}$ & Jet-Fan & Ducting & location \\
\hline Fire Scenario 1 & & & & & & $B 3(C)$ \\
\hline Fire Scenario 2 & & & & & & $B 3(S)$ \\
\hline Fire Scenario 3 & & & & & & $B 3(C)$ \\
\hline Fire Scenario 4 & & & & & $B 3(C)$ \\
\hline Fire Scenario 5 & & & & & $B 3(C)$ \\
\hline Fire Scenario 6 & & & & & & $B 2(C)$ \\
\hline Fire Scenario 7 & & & & & $B 1(C)$ \\
\hline Fire Scenario 8 & & & & & $B 2(S)$ \\
\hline Fire Scenario 9 & & & & & & $B 3(E)$ \\
\hline Fire Scenario 10 & & & & & & $B 3(C)$ \\
\hline
\end{tabular}

(C) = fire is in the centre of the basement

(S) = fire is near the intake air side

(E) = fire is near the exhaust air side

$=$ available 
Furthermore, the inclusion of jet fans was simulated in FS5 to FS9. Make-up air was delivered by make-up air fans and then induced to the extraction zone by the jet fans. FS10 included the advantage of having ducting, as illustrated in Figure 2; in the extraction zone, the jet fans were removed and ducting was applied as the media of smoke extraction. The operation mode, equipment specification, and simulation scenarios are shown in Table 2. Figure 3 illustrates the variations in the location of the fire.

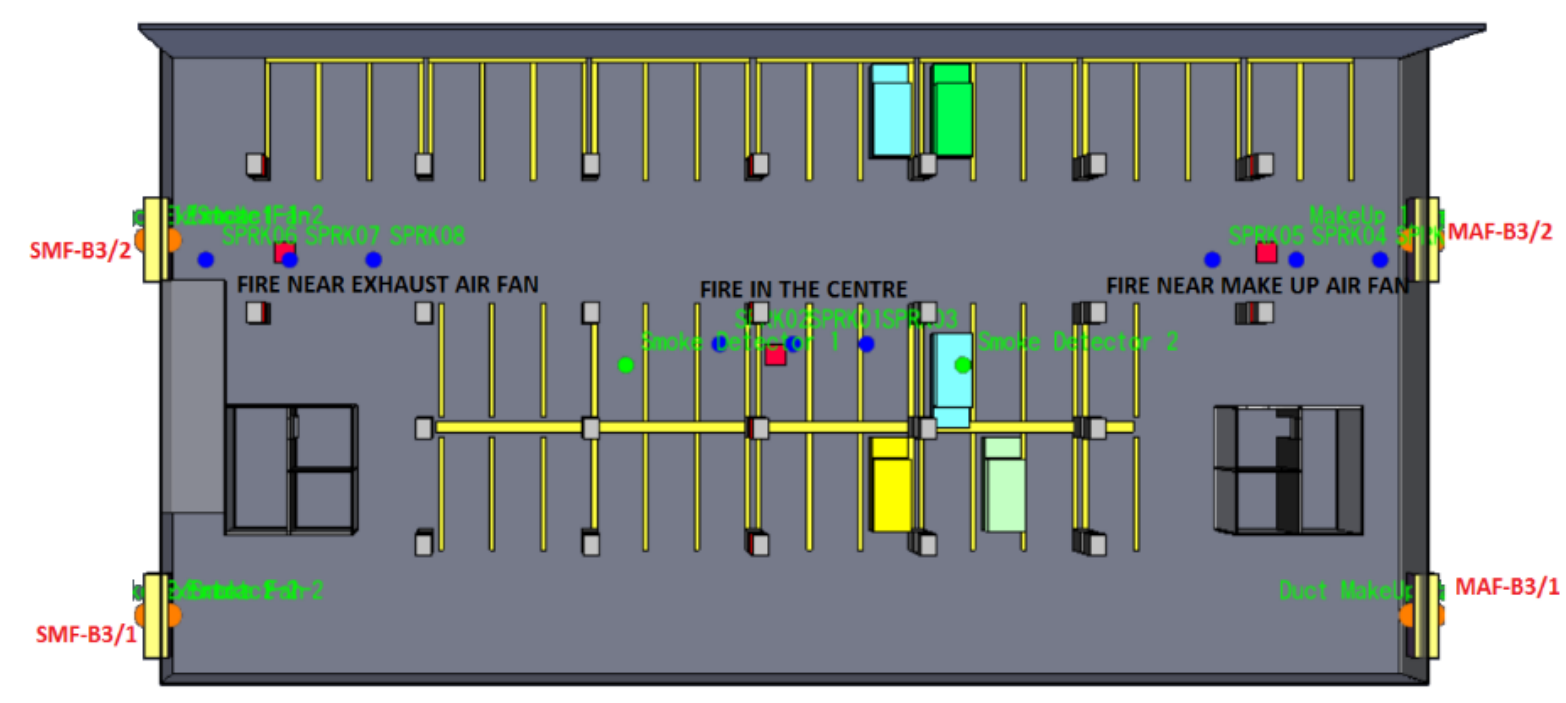

Figure 3 Location of the fire and sprinklers above fire source (red dots)

\section{RESULTS AND DISCUSSION}

When the fires were ignited at each location, they were located a significant distance below the ceiling sprinkler heads. There were three sprinklers in a row, each separated from each other by $4 \mathrm{~m}$. The sprinkler in the middle was located $2.5 \mathrm{~m}$ above the fire source. The sprinklers are generally assumed to activate immediately for a fire sizes of $2 \mathrm{MW}$. When the heat spreads in to the adjacent areas, numerous sprinkler heads may activate due to the elevated ambient ceiling temperatures. When too many sprinkler heads activate, the water pressure is significantly reduced and the delivered water density decreases. This could result in ineffective sprinkler operation and an inability to control the fire. In this experiment, the sprinklers operated quickly for all intentional fire scenarios. The approximate sprinkler activation temperature after ignition was $57^{\circ} \mathrm{C}$

FS1: Neither sprinklers nor mechanical ventilation systems were provided. The simulation shows smoke movement within a period of less than 1,400 sec. Smoke filled the volume of basement 3 (B3) within less than $150 \mathrm{sec}$, and then rose upward through the ramp opening. Figure 4 shows that smoke subsequently filled basement 1 (B1) and a small volume of smoke started to fill basement 2 (B2). In a period of less than $1400 \mathrm{sec}$, B1 was completely filled with smoke and most likely a large part of B2 was filled as well. Visibility in B3 was diminished to less than $14 \mathrm{~m}$. A total loss of visibility would be expected and would have been very unlikely that any entry was available for firefighters to extinguish the fire since the basement was filled with smoke.

FS2: When there is no sprinkler system activation, an intentional fire can grow out of control. An HRR greater than $2 \mathrm{MW}$ can occur. However, this study is limited to the spread of smoke, the spread of flames is neglected, and the surface of the building structure is considered to be inert and adiabatic. Smoke filled B3 within $157 \mathrm{sec}$ after the ignition, and smoke subsequently spread upstairs through the ramp opening. B1 was filled first before smoke started to fill B2 due 
to the density of smoke, which is lighter than air. Unlike FS1, it took a longer time for the smoke to fill the basement; for example, in $\mathrm{t}=1800 \mathrm{sec}$ the smoke density was less in B1, but the room was completely filled with smoke at that time. Although less smoke was produced in FS2 compared to FS1, there would have been limited ability to fight the fire that had occurred due to reduced visibility and increased levels of toxicity caused by smoke, despite the fact that the firefighters could enter the space. It is very unlikely that successful entry and aggressive internal firefighting operations would be possible for such a fire.
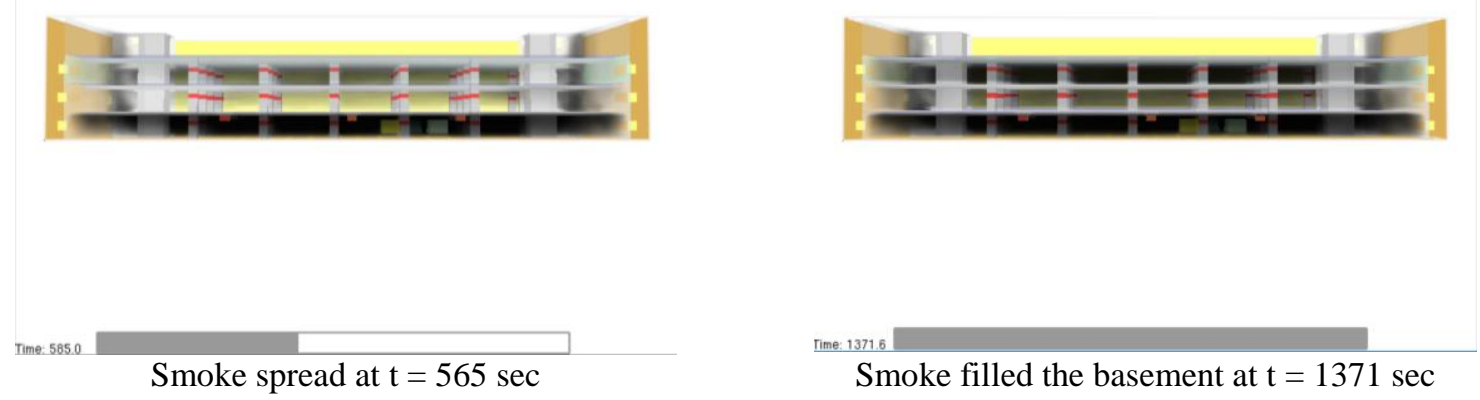

Figure 4 Smoke spread over time and soot visibility for FS1

FS3: The smoke produced started to move upward to the outside through the ramp opening. The activation of the sprinklers caused a reduction in HRR, meaning that the fire started to decay. Without forced air circulation by mechanical fans, air rises naturally. At $t=412 \mathrm{sec}$, the smoke was apparently cleared in B2. Because there was not a great amount of smoke produced in the basement complete with sprinklers, the smoke is not likely to flow outdoor instead of enter the above floors.

FS4: Fire occurred at the center of B3. Sprinklers and a central mechanical ventilation system were provided. The air-flow pattern can be seen in Figure 5. The smoke was cleared by $t=250$ sec, which is faster than in an unventilated basement.

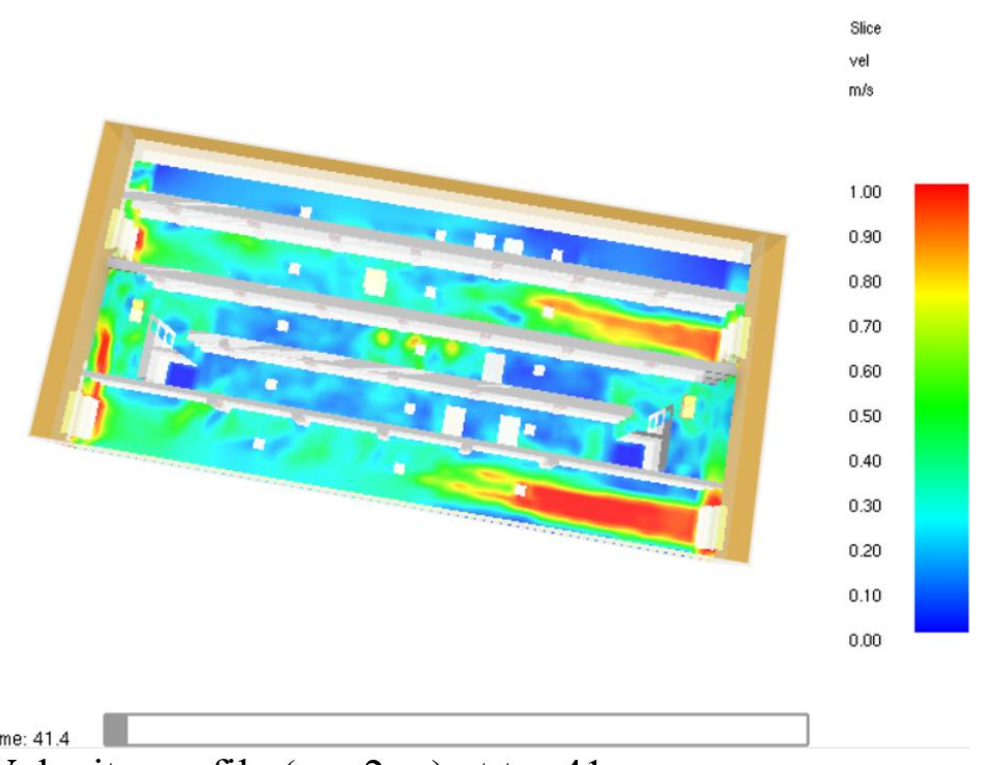

Velocity profile $(\mathrm{z}=2 \mathrm{~m})$ at $\mathrm{t}=41 \mathrm{sec}$

Figure 5 Velocity profile for FS4

FS5: Fire occurred at the center of B3. The basement was provided with a complete, active fire protection system, including sprinklers, jet fans, and similar configuration of mechanical fans to FS4. Two smoke-extraction fans with a capacity of $7.5 \mathrm{~m}^{3} / \mathrm{s}$ each were provided at one side of 
the basement. Two make-up air fans were provided at the opposite side, each with the same capacity of $7.5 \mathrm{~m}^{3} / \mathrm{s}$. Three rows of jet fans, with five fans in each row, distributed the make-up air to the air-discharge zone. The flow rate of each jet fans was $2 \mathrm{~m}^{3} / \mathrm{sec}$. The fire ignited for a moment and was quickly extinguished approximately $20 \mathrm{sec}$ after the growth of the flaming fire. The simulation's result shows that the smoke was apparently cleared within $216 \mathrm{sec}$, which is faster than in the basement without jet fans. At the start of the fire, the smoke spread radially in every direction. Because of the jet fans, the smoke-flow pattern then changed to be in one direction, which was from the intake fan to the discharge zone.

FS6: This scenario is similar to FS5, except that the fire started in the center of B2. The first sprinkler was located above the fire source, and the other two sprinklers were located to the left and right sides of the first sprinkler. The distance between the sprinklers was $2 \mathrm{~m}$, and they were $2.5 \mathrm{~m}$ above floor level. The simulation shows that the smoke initially spread radially in the first stage of the fire, but then finally changed to flow in one direction toward the extract side. The smoke was cleared faster than in FS5, in a time of approximately $150 \mathrm{sec}$.

FS7: The fire was at the center of B1. The scenario is similar to both FS6 and FS5. The smoke clearance time was longer than for the fire in the lower level. There was still a small amount of smoke at $\mathrm{t}=283 \mathrm{sec}$, and the smoke was finally cleared in a period of less than $5 \mathrm{~min}$.

FS8: The same scenario as FS5 and FS6 was applied here, but the fire was set in a different location: in B2 near the location of the smoke-extraction fan. The smoke was cleared faster, by $\mathrm{t}$ $=283 \mathrm{sec}$.

FS9: The fire was in B3, located near the smoke-extraction fan, and consisted of a fire ignited by a fuel pool of $1 \mathrm{~m}^{2}$ located near the side with the smoke extraction. The same scenario as both FS5 and FS6 was also applied here. The smoke was cleared faster than for FS8, in approximately $122 \mathrm{sec}$.

FS10: The fire broke out in the middle of B3. The jet fans in the exhaust zone were replaced with high-level and low-level ductwork. The result of the simulation is shown in Figure 6. The smoke was cleared within less than $90 \mathrm{sec}$, which is the fastest among the ten scenarios discussed in this study.

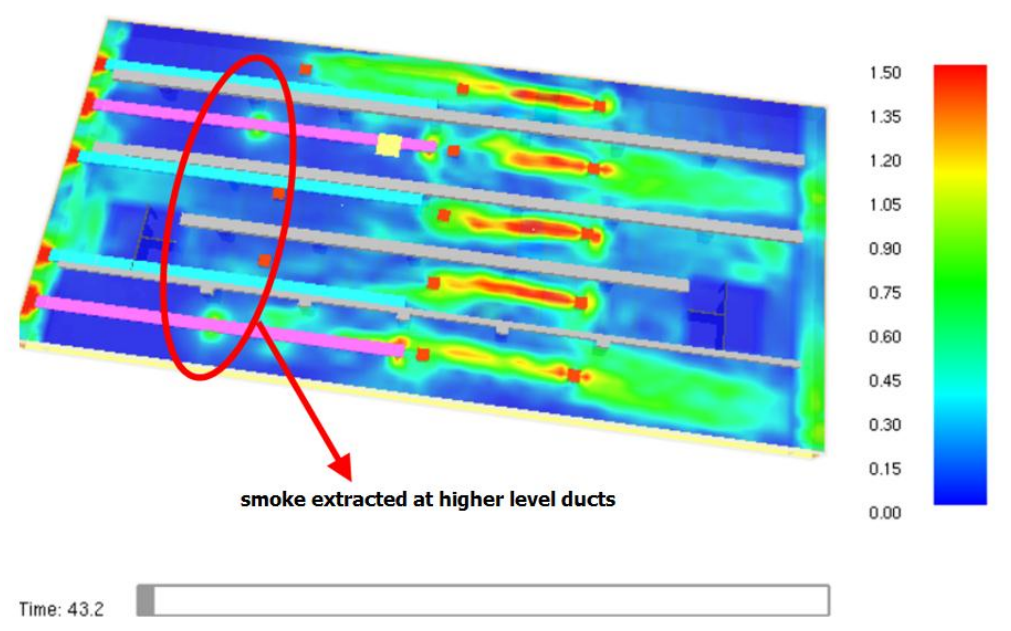

Figure 6 Smoke spread over time and soot visibility for FF10 at $\mathrm{t}=43.2 \mathrm{sec}$ 


\section{CONCLUSION}

Even though a fire in a basement is a rare event and such a fire may be initiated in numerous ways, it is important to provide sprinklers and mechanical ventilation in underground parking garages. Sprinklers are the vital components in an active fire protection system. When sprinkler activation does not occur, such as in a space with no sprinklers, the ambient ceiling temperatures are increased and the fire is allowed to continue to burn. In comparison, where there are no sprinklers applied and proper ventilation, the production of smoke exceeds the capacity for smoke extraction, which causes the whole basement to be filled by smoke. Even when sprinklers are provided, the absence of a smoke exhaust fan might lead to smoke remaining in the basement for a prolonged period of time, in spite of the fact that the fire is completely extinguished by the sprinklers. The provision of jet fans may result in migration of smoke that is faster than conventional ventilation without jet fans. This study showed that having sprinklers, make-up air fans, smoke-extraction fans, jet fans, and ductwork gives the fastest smoke-removal time in a basement fire.

\section{ACKNOWLEDGEMENT}

The authors would like to thank Fire Safety Engineering Research Group and Thermodynamics Laboratory of Department of Mechanical Engineering, Universitas Indonesia for providing supports and great discussion.

\section{REFERENCES}

Arini, D., Pancawardani, F., Santoso, M.A., Sugiarto, B., Nugroho, Y.S., 2017. Froude Modelling of Fire Phenomena: Observation of Fire-induced Smoke Movement in Basement Structure for Fire Fighting Purpose. Engineering Physics International Conference, EPIC 2016, Procedia Engineering, Volume 170, pp. 182-188

ASHRAE Handbook - Application, 2015. American Society of Heating, Refrigerating and Air Conditioning Engineers. GA-Atlanta

BS 7346-7:2006. Components for Smoke and Heat Control Systems - Part 7: Code of Practice on Recommendations and Calculation Methods on Smoke and Heat Control Systems for Covered Car Parks, 2006. British Standards

Cheng, Y.P., John, R., 2002. Experimental Research of Motorcar Fire. Journal of China University of Mining and Technology, Volume 31(6), pp. 557-560

Chow, W.K., 1998. On Safety Systems for Underground Car-parks. Tunnelling and Underground Space Technology, Volume 13(3), pp. 281-287

CIBSE Guide B: Heating, Refrigerating, Air Conditioning and Refrigeration, 2005. The Chartered Institution of Building Services Engineers. London, UK

Deckers, X., Haga, S., Sette, B., Merci, B., 2013a. Smoke Control in Case of Fire in a Large Car Park: Full-scale Experiments. Fire Safety Journal, Volume 57, pp. 11-21

Deckers, X., Haga, S., Sette, B., Merci, B., 2013b. Smoke Control in Case of Fire in a Large Car Park: CFD Simulations of Full Scale Configurations. Fire Safety Journal, Volume 57, pp. 22-34

Enright, T., 2014. Impact of Jet Fan Ventilation Systems on Sprinkler Activation. Case Studies in Fire Safety, Volume 1, pp. 1-7

Gao, R., Li, A., Hao, X., Lei, W., Deng, B., 2012. Prediction of the Spread of Smoke in a Huge Transit Terminal Subway Station under Six Different Fire Scenarios. Tunneling and Underground Space Technology Journal, Volume 31, pp. 128-138

Horvarth, I., Beeck, J.v., Merci, B., 2013. Full-scale and Reduced-scale Tests on Smoke Movement in Case of Car Park Fire. Fire Safety Journal, Volume 57, pp. 35-43 
Hwang, C.C., Edwards, J.C., 2005. The Critical Ventilation Velocity in Tunnel Fires - A Computer Simulation. Fire Safety Journal, Volume 40, pp. 213-244

Ingason, H., Lonnermark, A., 2005. Heat Release Rates from Heavy Goods Vehicle Trailer Fires in Tunnels. Fire Safety Journal, Volume 40, pp.646-668

Lu, S., Wang, Y.H., Zhang, R.F., Zhang, H. P., 2011. Numerical Study on Impulse Ventilation for Smoke Control in an Underground Car Park. Procedia Engineering, Volume 11, pp. 369-378

Mangs, J., Keski-Rahkonen, O., 1994. Characterisation of the Fire Behaviour of a Burning Passenger Car. Part II: Parameterization of Measured Rate of Heat Release Curves. Fire Safety Journal, Volume 23, pp. 37-49

NFPA 13: Standard for the Installation of Sprinkler Systems, 2013. National Fire Protection Association. 1 Batterymarch Park, Quincy, MA

Pangaribuan, A., Fadhil, Santoso, M.A., Nugroho, Y.S., 2016. Controlling Fire Growth in Electrical Cable Compartment by Reducing Oxygen Concentration at Horizontal Orientation. International Journal of Technology, Volume 7(2), pp.332-342

Shipp, M., Spearpoint, M., 1995. Measurements of the Severity of Fires Involving Private Vehicles. Fire and Materials, Volume 19, pp. 143-151

Sujatmiko, W., Dipojono, H.K., Soelami, F.X.N., Soegijanto, 2014. Performance Based Fire Safety Evacuation in High-rise Building Flats in Indonesia - A Case Study in Bandung. Procedia Environmental Sciences, Volume 20, pp. 116-125

Tilley, N., Deckers, X., Merci, B., 2012. CFD Study of Relation between Ventilation Velocity and Smoke Backlayering Distance in Large Closed Car Parks. Fire Safety Journal, Volume 48, pp. 11-20

Vauquelin, O., Telle, D., 2005, Definition and Experimental Evaluation of the Smoke "Confinement Velocity" in Tunnel Fires. Fire Safety Journal, Volume 40, pp. 320-330

Viegas, J.C., 2010. The Use of Impulse Ventilation for Smoke Control in Underground Car Parks. Tunnelling and Underground Space Technology, Volume 25, pp. 42-53

Wu, F., Jiang, J., Zhou, R., Zhao, D., Shi, L., 2017. A New Natural Ventilation Method for Fire-induced Smoke Control in a Common Subway Station. International Journal of Ventilation, Volume 0(0), pp.1-18 